\title{
Penguatan Mitigasi Radikalisme Melalui Pembelajaran Berbasis Kearifan Lokal pada Taman Kanak-Kanak di Kota Palopo
}

\author{
Nurdin Kaso ', Subhan ${ }^{2}$, Dodi Ilham ${ }^{3}$, Nurul Aswar 4* \\ 1, 2, 3, 4, Institut Agama Islam Negeri Palopo \\ 17nurdink@iainpalopo.ac.id, ${ }^{4}$ nurul_aswar@iainpalopo.ac.id
}

\begin{abstract}
Abstrak
Kegiatan pengabdian ini dilatarbelakangi oleh paparan radikalisme yang semakin masif di tengah-tengah masyarakat pra sekolah. Untuk itu, dalam upaya membentengi para guru dan anak didik, maka dilaksanakan sebuah pelatihan yang bertujuan untuk memberikan penguatan konseptual dan teknis mitigasi Radikalisme melalui Pembelajaran Berbasis Kearifan Lokal bagi 10 lembaga PAUD di Kota Palopo. Selama proses pelatihan berlangsung para peserta dibekali dengan kemampuan konseptual dan teknis selama 2 hari yang terbagi dalam 4 sesi yang didalamnya terjabar konsep dasar, pola, model, rancangan serta simulasi pembelajaran mitigasi radikalisme berbasis kearifan lokal. Keseluruhan sesi berjalan sesuai dengan perencanaan terbukti dari tingginya prosentase jumlah peserta (guru) yang mampu menguasai kompetensi capaian dan aktif terlibat dalam keseluruhan proses pelatihan.
\end{abstract}

Kata Kunci: mitigasi, radikalisme, kearifan lokal, taman kanak-kanak

\section{Pendahuluan}

Dewasa ini, radikalisme menjadi faktor kunci baik buruknya transpormasi bertindak individu maupun kelompok masyarakat (Golberstein et al., 2020). Hal ini diakibatkan oleh misinterpretasi mendalam yang timbul terhadap konsep-konsep fundamentalis terutama pada konsep peperangan dan perdamaian (Yusof \& Nasir, 2010). Fatalisme pemahaman tersebut tidak jarang melahirkan berbagai aksi teror (terorisme), kekerasan, bulliying dan intoleransi yang berlebihan baik atas dasar ras maupun agama.

Peristiwa yang terjadi di New York Amerika Serikat; World Trade Center pada 11 September 2001 yang menewaskan lebih dari 3000 jiwa adalah contoh nyata tindakan radikal. Demikian juga serentetan kejadian serupa yang terjadi di Indonesia sejak tahun 1985 yakni Bom Candi Borobudur dan Bom Bursa Efek Jakarta serta Kedubes Filipina pada tahun 2000 (Tribun, 2016). Bahkan aksi teror tersebut sampai pada Kota Palopo dimana Bom meledak di Polres Palopo pada tahun 2013 (Kompas Media, 2013).

Berbagai aksi tersebut mengindikasikan masifnya penyebaran konsep-konsep radikalisme tengah-tengah masyarakat. Terlebih pada lingkungan keluarga dan sekolah, transformasi penggunaan gadget; internet, game online, serta media sosial oleh anak- 
anak dan remaja akhir-akhir ini tentu memberi peluang besar kemunculan nomophobia (Hafni, 2019) bahkan digital natives (Pratiwi, 2018) pada diri anak.

Hal tersebut secara otomatis memberikan anak akses terhadap konten-konten radikal berbasis internet dan game online. Hal ini berpotensi menimbulkan berbagai tindak radikal seperti kekerasan, bullying dan intoleran di lingkungan sekolah. Khasanah (2013) melaporkan dalam penelitiannya bahwa sebagian besar anak TK yang terpapar gadget baik sebagai pemakai aktif atau memakai gadget orang tuanya memiliki perilaku yang cenderung radikal. Anak sering mengejek (membuli) temannya, berkata kasar bahkan sampai pada tindakan fisik seperti memukul, tidak sabar menunggu giliran dan suka merebut mainan temannya secara paksa.

Penomena tersebut juga berkaitan erat dengan iklim pembelajaran dan pola pengasuhan yang dilakukan orang tua. Misalnya pada konteks pemberian hukuman (punishment) oleh guru, apabila dilakukan dengan cara yang kurang mendidik maka bertolak belakang dengan respon yang terbentuk pada diri anak. Demikian juga halnya dengan pola pengasuhan yang yang tidak sesuai dengan karaktersitik anak, maka tentu menimbulkan perilaku berlawanan dengan kehendak orang tua. Sebagaimana hasil penelitian yang dilakukan Zidni (2018) bahwa sejumlah anak yang menjadi respondennya berperilaku kasar dan agresif meniru tindakan gurunya sendiri ketika menghukum anak lainnya. Perbuatan anak tersebut sepintas seperti kegiatan drama atau "main-main", namun perikau tersebut ditunjukkan dalam intensitas yang cukup signifikan sehingga menjadi suatu kebiasaan.

Hal serupa juga terjadi di beberapa TK di Kota Palopo. Studi pendahuluan yang dilakukan peneliti menunjukkan dari sejumlah anak yang diobservasi, terdapat beberapa anak seperti memberikan label "julukan" kepada temannya sendiri yang notabene berbeda keyakinan (agama). Misalnya, "jangan bermain dengan si Andi, si Andi kan orang kristen". Penomena lain yang ditemukan peneliti juga seperti ketika peneliti bertemu dan berinteraksi sambil berkenalan dengan anak saat jam istirahat, maka ada anak yang mengatakan "pak, kalau ini dia anak miskin, kalau ini dia kristen" dan kata-kata lainnya yang menunjukkan simbolitas (wawancara, 2018).

Berdasarkan hal tersebut, maka diperlukan keterampilan orang tua terutama guru sebagai pendidik di Taman Kanak-Kanak yang memadai dalam meerancang pembelajaran yang dapat mengatasi perilaku radikal anak. Melalui pelatihan ini, guru akan dibekali bagaimana memahami konsep dasar radikalisme dalam kaitannya dengan pelaksanaan pembelajaran. Disamping itu, guru juga dapat menelaah unsur-unsur yang berkaiatan dengan mitigasi radikalisme pada anak. Guru juga dapat secara teknis merancang media stimulasi perkembangan berbasis nilai-nilai kearifan lokal dalam melakukan mitigasi radikalisme.

Isu radikalisme sudah lama diperbincangkan. Apalagi radikalisme yang sudah mengarah ke terorisme. Untuk itu, apabila ditelusuri lebih jauh, ternyata banyak ahli yang telah melakukan riset terkait hal ini. Namun demikian, kajian tentang keterkaitan dunia pendidikan anak usia dini dengan radikalisme terutama terhadap anak dan guru, masih jarang dilakukan. Sejatinya, sudah ada peneliti yang mengaitkan radikalisme dengan konteks kearifan lokal termasuk dengan budaya dan nilai-nilai luhur daerah. Namun belum ada secara khusus mengaitkan radikalisme dengan konteks anak, guru, dan 
pembelajaran anak usia dini. sehingga penyelesaian dan mitigasi radikaisme di kalangan pendidikan anak usia dini dapat lebih epektif dan tepat sasaran. Sebagaimana penelitian terdahulu yang dilakukan oleh (Fuad, 2018), dengan judul Gerakan Kultural dan Pemberdayaan: Sebuah Imun terhadap Radikalisasi di Sanggar Sekar Jagad Sukoharjo pencegahan radikalisasi melalui gerakan kultural dan pemberdayaan, Achmad Wahidy melalui penelitian Budaya dan Kearifan Lokal Sebagai Benteng Radikalisme (Wahidy, 2018), Rokhmad, (2012) dengan judul Radikalisme Islam dan Upaya Deradikalisasi Paham Radikal Abu Rokhmad, Zulfani Sesmiarni (2015) juga telah melakukan penelitian serupa, serta Widyaningsih, dkk (Widyaningsih et al., 2017).

\section{Mitigasi Radikalisme}

Istilah radikaslime secara harfiah berasal dari akar kata "radic" yang berarti akar (Kusuma \& Azizah, 2018). Pada dasarnya istilah ini bermakna universal sehingga digunakan oleh para ahli dalam berbagai konteks. Namun istilah ini familiar digunakan pada pada kajian-kajian filsafat. Sebagaimana digunakan untuk mengistilahkan salah satu aspek dasar filsafat yakni berfikir radikal (Schofield, 2004). Artinya, tindakan berfikir terhadap persoalan tertentu sampai ke akar-akarnya.

Sementara tu, literatur modern yang digagas para peneliti negara-negara barat sering mengaitkan istilah tersebut dengan aksi kekerasan dan terorisme (Wong et al., 2019). Di lain pihak, radikalisme juga kerap dikaitkan dengan istilah fanatis, militan dan ekstrimis (Yusof \& Nasir, 2010). Kaitan ini lahir karena tindakan-tindakan tersebut menurut para ahli lahir atas dasar pemikiran radikal (mendalam) yang dilakukan seseorang atau kelompok orang terhadap konsep-konsep fundamental dalam agama dan ras.

Hal ini sesuai dengan analisis akademik yang dilakukan Esposito (1997) bahwa penyebab radikalisme bertalian erat dengan adanya perbedaan persepsi pada beberapa konsep keagamaan tentang jihad, perang dan perdamaian. Sehingga motif dari tindakan radikal atau kekerasan selalu berpangkal pada paham radikal (radikalisme) atas dasar jihad agama. Dengan demikian, dapat dikatakan bahwa radikalisme adalah pemikiran mendalam terhadap suatu konsep atau persoalan sehingga menimbulkan keyakinan yang mendorong lahirnya suatu tindakan atau perilaku atas dasar pemikiran tersebut.

Radikalisme dan usia dini seolah-olah tidak berkaitan secara hirarkis. Namun demikian, apabila dikaji berdasarkan prinsip-prinsip neurolgis dan psikologi perkembangan anak, justru terdapat hubungan yang sangat fundamental. Hal ini akan semakin mengerucut bila terlebih dahulu dipahami bagaimana hakikat anak usia dini dari sudut pandang pertumbuhan dan pekembangan, kaitan neurologi dengan perkembangan, juga dikatikan dengan aspek perkembangan lainnya seperti bahasa dan motorik.

Bersandar pada hal tersebut, untuk memahami hakikat anak usia dini maka baiknya berangkat dari istilah yang sering disematkan padanya yaitu "usia emas" atau the golden age (Fahmi \& Ichsan, 2018). Istilah ini digunakan untuk menggambarkan besarnya potensi tumbuh kembang anak yang terjadi pada periode usi dini. Perkembangan motorik, perkembangan bahasa, kognitif, sampai pada perkembangan sosial-emosional merupakan perkembangan yang cukup dominan (Neaum, 2010). Kesemuanya itu bersifat komperehensif dan terpadu; memiliki rentang dan karakteristik tugas perkembangan 
yang saling melengkapi. Membangun anak menjadi pribadi yang unik dengan ritme perkembangan yang sangat progresif.

Pada perkembangan kognitif, secara neurologis dalam otak anak tertanam miliaran sel saraf yang siap mengadakan sambungan setiap saat (Percy, 2006). Hal ini menyebabkan proses asimilasi dan akomodasi informasi dalam otak begitu cepat. Pada aspek bahasa, pemerolehan bahasa (languange acquisition) pada anak berkembang sangat pesat. Fonologi, semantik, dan panjang ujaran yang mampu dilakukan anak membuatnya memahami pembicaraan (komprehensi) 10 kali lebih cepat daripada kemampuan menggunakan (produksi) bahasa. Hal ini lebih baik dari yang dapat dilakukan orang dewasa (Arsanti, 2014). Begitu juga dengan kemampuan sosial emosionalnya, anak usia dini terutama pada rentang usia 5-6 tahun sudah dapat menempatkan ekspresi emosi seperti sedih, senang dan kecewa terhadap respon yang tepat (Feldman, 2014). Untuk itu, anak akan merespon sesuai dengan penomena atau rangsangan yang datang dari luar dirinya. Hal ini tentu berpengaruh terhadap persepsi dan pandangannya terhadap hal-hal di luar dirinya.

Konsep nilai dan perilaku yang ditampilkan anak sebagai manipestasi dari keseluruhan potensi tumbuh kembangnya berkaitan erat dengan lingkungannya. Signifikansi perkembangan kognitif, pemerolehan bahasa yang memadai, serta sosial emosional yang berkembang pesat mempercepatnya meniru dan mengiplementasikan konten-konten radikal yang dikonsumsinya baik dari internet (digital natives) maupun secara langsung dari lingkungannya (Pratiwi, 2018). Dengan demikian, beberapa laporan penelitian, perilaku radikal pada anak usia dini kerap ditunjukkan dalam bentuk tindakan kekerasan seperti memukul, agresif, mengejek, tidak sabar menunggu giliran dan suka merebut alat main temannya (Khasanah, 2013; Zidni, 2018)

Berdasarkan hal di atas, maka mitigasi diperlukan sebagai bentuk pencagahan. Mitigasi dapat dipahami sebagai suatu tindakan untuk mengurangi dampak dari suatu perbuatan atau peristiwa (Permana et al., 2012). Dalam kasus kebencanaan, mitigasi sering digunakan untuk membahasakan tindakan yang dilakukan dalam rangka pengurangan resiko terhadap bencana alam yang tengah terjadi (Peraturan Menteri Dalam Negeri, 2006). Apabila pengertian ini dikaitkan dengan konsep radikalisme, maka mitigasi radikalisme dimaknai sebagai bentuk tindakan pengurangan bahkan pencegahan paham serta tindakan radikalisme.

\section{Kearifan Lokal (Local Wisdom)}

Mitigasi radikalisme melalui pembelajaran berbasis kearifan lokal sejatinya berupaya meredam pemikiran dan tindakan radikal dengan kembali kepada jati diri masyarakat yang sesungguhnya menyatu dengan alam sebagai tempat tinggal alamiah. Dalam hal ini, NakhornThap (1996) juga berpendapat demikian, di mana menurutnya kearifan lokal merupakan "basic knowledge" pengetahuan dasar yang timbul dari kehidupan yang menyatu dengan alam. Kearifan lokal berkorelasi dengan kebudayaan berbentuk abstrak dan kongrit dalam praktik kehidupan bermasyarakat sehingga keduanya lahir dari pengalaman dan ni-nilai kehidupan.

Konteks yang sama dengan apa yang diungkap oleh Kongprasertamorn (2007) bahwa kearifan lokal merujuk pada suatu pengetahuan yang berasal dari pengalaman masyarakat yang terakumulasi dari pengetahuan setempat (lokal). Dengan berasal dari 
pengalaman, maka kearifan lokal dapat ditemukan baik pada mayarakat atau pun suatu individu.

Dalam konteks yang sama, Meliono (2011) memperluas terminologi kearifan lokal sebagai sebuah "pengetahuan yang lahir dari pengalaman"; menjadi lebih aksplisit. Menurutnya kearifan lokal merupakan bentuk ekspresi etnik masyarakat Indonesia termasuk aktivitas, gagasan, dan kegiatan yang mereka lakukan dalam hal menjalankan pekerjaan sehari-hari. Dari sini dapat dipahami bahwa kearifan lokal berkaitan dengan seluruh aktivitas yang berlangsung dalam sebuah masyarakat.

Atas dasar itu, maka kearifan lokal seringkali dianggap dapat berperan sebagai cermin jati diri masyakarakat itu sendiri. Jati diri yang mereresentasikan identits budaya sebagai satu kesatuan nilai yang berkembang, hidup, dan diyakini masyarakat sebagai dasar berpikir dan bertindak luhur. Akibatnya, perubahan kecenderungan sosial yang dimotori oleh perubahan budaya masyarakat dimana bergantung juga terhadap perkembangan tekhnologi dan informasi, disertai juga dengan perubahan kearifan lokal masyarakat setempat (Pornpimon et al., 2014).

Konsepsi kearifan lokal yang menjadi cermin jati diri sebah budaya masyarakat releavan dengan terminologi dasar budaya itu sendiri, yakni hasil upaya terus menerus dari manusia dalam ikatan masyarakat. Hal tersebut tidak hanya mencakup hal-hal yang telah dan sedang berlangsung, tetapi juga melingkupi seluruh bentuk cita-cita yang masih harus diwujudkan termasuk norma, pandangan hidup dan sistem nilai.

Kearifan lokal sebagai cermin dan jarti diri masyarakat dalam konteks budaya sebagai esensi dari berbagai sudut pandang di atas, maka dapat diidentifikasi beberapa batasan atau karakteristik kearifan lokal, bahwa (a) kearifan lokal merupakan sekumpulan pengatahuan yang lahir dari pengalaman kelompok masyarakat tertentu, (b) kearifan lokal berbentuk abstrak (ide, pemikiran atau nilai) dan kongkrit (tertuang dalam praktik atau aktivitas luhur kehidupan bermasyarakat), (c) kearifan lokal mengikuti perubahan ide dan perilaku (budaya) masyarakat, akibatnya apabila budaya berubah maka kearifan lokal juga mengikuti perubahan tersebut dan (d) perkembangan tekhnologi dan informasi mempengaruhi perubahan budaya sehingga berubah pula kearifan lokal dari masyarakat tersebut.

Sebagai ide dan nilai, kearifan lokal yang berkembang di Luwu dalam konteks mitigasi radikalisme memiliki berbagai macam nilai luhur, di antaranya: (1) Alempureng (jujur): merupakan suatu nasihat atau petunjuk mengenai kejujuran yang berasal dari nenek moyang orang Bugis zaman dahulu untuk anak cucunya yang berisi aturan menjalani hidup, kehidupan dan aturan menjalin hubungan dengan sesama manusia dan sang pencipta yang harus dipatuhi dan dijunjung tinggi. (2) Amaccangeng (cerdas): adalah suatu nasehat yang berisi anjuran untuk bersikap cerdas; pintar menempatkan diri dan bergaul dalam masyarakat baik yang berbeda keyakinan, kebudayaan, adat istiadat serta norma dan nilai yang berlaku bagi masyarakat tersebut. (3) Aresong (kerja keras: yaitu suatu nasehat yang berisi anjuran untuk selalu bekerja keras, berupaya dan berusaha untuk memenuhi tuntutan kehidupan jalan yang baik dan halal, tidak bermalas-malasan dan selalu berikhitiar dengan maksimal di setiap usaha yang dilakukan. (4) Adele' (Adil): merupakan suatu nasehat agar selalu bersikap adil terhadap sesama, menempatkan sesuatu sesuai dengan porsinya. 


\section{Metode Pelaksanaan}

Metode dan teknik dalam pengabdian ini bertujuan untuk menentukan teknik operasional yang dipakai sebagai pegangan dalam mengambil langkah-langkah tindakan selama pelaksanaan pendampingan. Untuk alasan tersebut, pengabdian ini menggunakan strategi Partisipation Action Research (PAR) yang dilakukan berdasarkan fokus pengabdian yang telah ditentukan.

Operasionalisasi pelaksanaan pengabdian diawali dengan melakukan pemetaan yang dilakukan dalam rangka menentukan TK/RA yang akan menjadi target pengadian. Kriteria penentuan ini didasarkan pada hasil studi pendahuluan yang dilakukan peneliti sebelumnya. Dalam hal ini, peneliti melakukan cross check untuk memastikan bahwa guru di TK/RA tersebut layak untuk mendapatkan pendampingan.

Selanjutnya dilakukan persiapan pelaksanaan pendampingan dengan membentuk kepanitian, menyusun silabus kegiatan, run down kegiatan, modul, serta alat dan bahan pelaksanaan kegiatan yang digunakan selama kegiatan berlangsung. Setelah persiapan selesai, selanjutnya melaksanakan kegiatan dengan mengimplementasikan semua perencanaan yang telah dilakukan. Target peserta masing-masing 4 orang guru dari 10 lembaga PAUD TK/RA yang telah ditetapkan pada tahap pemetaan. Selesai pelatihan, maka tim pengabdian menindaklanjuti kemampuan guru dalam melaksanakan mitigasi radikalisme berbasis kearifan lokal di lembaga masing-masing.

Secara berkala, tim pengabdian juga melakukan monitoring dan evaluasi guna melakukan pengumpulan data terkait peningkatan konsep dan praktik mitigasi radikalisme berbasis kearifan lokal yang telah diterapkan oleh guru di sekolah. Guru harus melaporkan bagaimana perkembangan penomena radikalisme di sekolah termasuk yang diwujudkan anak dalam bentuk perilakunya sehari-hari di sekolah. Guru dibekali ceck list untuk memonitor penomena yang muncul. Setiap monitoring dan evaluasi guru harus menyampaikan hal tersebut dan peneliti melakukan pendalaman dengan melakukan wawancara dan dokumentasi.

Sumber data dalam pengabdian ini adalah 40 guru dari 10 lembaga TK yang ada di Kota Palopo. Sasaran dan teknik pengumpulan data yang digunakan dalam laporan pengabdian ini menyangkut pemetaan potensi paparan radikalisme di kalangan guru, menguji epektivitas pelatihan mitigasi radikalisme berkaitan dengan motivasi guru dan kemampuan konseptual dan teknis guru dalam memitigasi radikalisme melalui pembelajaran berbaasis kearifan lokal setelah mengikuti pelaksanaan pelatihan.

Berdasarkan hal tersebut, berikut dipaparkan teknik, sumber daya dan analisis data yang digunakan:

\section{Kuesioner}

Kuesioner digunakan untuk melakukan pemetaan (penjaringan) lembaga PAUD yang berpotensi terpapar radikalisme. Indikator potensi radikalisme tertuang dalam butirbutir kuesioner, diantaranya: (a) pandangan guru terhadap penomena radikalisme di Indonesia, (b) intensitas guru mengakses (sengaja dan tidak sengaja) konten radikalisme melalui media sosial, (c) pendapat guru mengenai konsep jihad membela agama, intoleransi terhadap pemeluk agama lain, sikap ekslusif terhadap budaya dan keyakinan berbeda, serta kemampuan ideologi Pancasila mendukung persatuan dan kesatuan umat 
islam di Indonesia, dan (e) pendapat guru mengenai fakta beberapa paparan radikalisme di dunia pendidikan. Data yang diperoleh dari kuesioner dianalisis secara kualitatif menggunakan skala likert dengan 5 kriteria yaitu Sangat Setuju (SS) skor 5, Setuju (S) skor 4, Netral (N) skor 3, Tidak Setuju (TS) skor 2 dan Sangat Tidak Setuju (STS) skor 1. Kesimpulan dibuat dengan menjumlah hasil skor dari setiap kriteria tersebut.

\section{Wawancara}

Wawancara bertujuan untuk memperkuat data yang diperoleh dari hasil kuesioner. Jawaban para responden dari kuesioner diperdalam menggunakan wawancara tidak terstruktur untuk mengetahui alasan-alasan dan latar belakang para responden memberikan jawaban pada angket sehingga dapat diketahui latar belakang secara komperehensif apa dan mengapa para responden memberikan sebuah jawaban.

\section{Observasi}

Observasi digunakan untuk melihat keaktifan peserta dalam proses pelaksanaan pelatihan. Dalam lembar observasi, beberapa aspek keaktifan yang diamati antaralain: (a) intensitas kehadiran peserta, (b) upaya peserta untuk mencatat materi yang dianggap penting, (c) kepatuhan peserta mengikuti arahan panitia dan pembicara, (d) kemampuan menyampaikan pertanyaan kepada pemateri, (e) keaktifan diskusi bersama rekan, dan (f) kemampuan melakukan simuluasi pembelajaran. Lembar observasi menggunakan Skala Thurstone dengan kriteria aktif skor 1 dan tidak aktif dengan skor o. Dengan demikian, secara sederhana dapat ditentukan bahwa seluruh peserta dinyatakan aktif secara klasikal apabila dalam lembar observasi $80 \%$ dari 40 peserta berkatogori aktif dan sebaliknya dinyatakan tidak aktif.

\section{Tes Penguasaan Kompetensi Konseptual dan Teknis}

Tes penguasaan kompetensi konseptual dilaksanakan setelah peserta selesai mengikuti pelatihan. Dalam tes ini, aspek yang diukur antaralain (a) memahami konsep dasar mitigasi radikalisme dan kearifan lokal, (b) mempolakan mitigasi radikalisme melalui kearifan lokal, (c) memahami prinsip, unsur dan perangkat model pembelajaran mitigasi radikalisme melalui kearifan lokal dan (e) merancang perangkat pembelajaran mitigasi radikalisme melalui kearifan lokal.

Tes diberikan kepada peserta berbentuk uraian berjumlah 7 butir soal. Jawaban peserta dianalisis menggunakan sistem pembobotan dimana masing-masing soal memiliki bobot yang berbeda sehingga skor akhir untuk setiap peserta adalah jumlah dari seluruh bobot dari setiap soal yang dijawab benar.

Selanjutnya penguasaan teknis mitigasi radikalisme melalui pembelajaran berbasis kearifan lokal diukur menggunakan tes uji kompetensi teknis. Tes ini digunakan untuk melakukan penilaian terhadap kemampuan para guru dalam membuat perangkat pembelajaran saat pelaksanaan pelatihan. Aspek yang dinilai antaralain: (a) kemampuan guru dalam membuat tema dan jaring tema yang sesuai dengan karakteristik pembelajaran mitigasi radikalisme berbasis kearifan lokal, (b) kemampuan guru dalam membuat Rencana Pelaksanaan Pembelajaran Harian (RPPH) yang terdiri dari pendekatan, metode, teknik. media, serta penggunaan tema dan jaring tema yang sesuai dengan pembelajaran mitigasi radikalisme berbasis kearifan lokal, (c) kemampuan guru dalam membuat media pembelajaran mitigasi radikalisme berbasis kearifan lokal, dan (d) 
performansi guru dalam mensimulasi pembelajaran mitigasi radikalisme berbasis kearifan lokal.

Tes ini berbasis penilaian portofolio (penilaian produk atau performa) yang ditunnjukkan oleh para peserta selama mengikuti pelatihan. Sistem penskoran berdasarkan kriteria standar masing-masing produk yang telah ditentukan. Selanjutnya skor dikumpulkan dan dibandingkan dengan kriteria kompeten (memenuhi $80 \%$ keriteria standar produk) atau tidak kompeten (tidak memenuhi $80 \%$ kriteria standar produk).

\section{Hasil dan Pembahasan}

\section{Kondisi Paparan Radikalisme pada Lembaga Taman Kanak-Kanak (TK) di Kota Palopo}

Sebelum melaksanakan pelatihan, tim pengabdian terlebih dahulu melakukan pemetaaan untuk menentukan lembaga TK yang kira-kira berpotensi terpapar radikalisme. Pemetaan dilakukan dengan melakukan wawancara. Setelah lembaga TK dapat ditentukan, tim pengabdian melakukan pendalaman untuk menentukan 40 guru dari 10 lembaga TK yang dianggap layak mengikuti pelatihan. Kelayakan ini ditentukan dengan menyebar angket kepada para guru yang berisi sejumlah pernyataan untuk ditanggapi. Pernyataan dikembangkan dari beberapa indikator yang didopsi dari berbagai konsep radikalisme yang digagas oleh BNPT dan lembaga atau perorangan (peneliti) terkait lainnya yang dapat menunjukkan seseorang terindikasi terpapar radikalisme. Indikator ini meliputi pandangan guru terhadap penomena radikalisme di Indonesia, intensitas guru mengakses (sengaja dan tidak sengaja) konten radikalisme melalui media sosial, pendapat guru mengenai konsep jihad membela agama, intoleransi terhadap pemeluk agama lain, sikap ekslusif terhadap budaya dan keyakinan berbeda, serta kemampuan ideologi Pancasila mendukung persatuan dan kesatuan umat islam di Indonesia, dan pendapat guru mengenai fakta beberapa paparan radikalisme di dunia pendidikan seperti kampus, lembaga sekolah termasuk lembaga PAUD.

Persepsi guru terhadap penomena radikalisme secara umum cukup agresif. Terutama pada dua butir pernyataan perbandingan penomena Khilafah Islamiah dengan Pancasila dan juga pada penomena Islam Arab dan Islam Nusantara. Lebih dari 45\% guru meyakini bahwa sistem Khilafah Islamiah jauh lebih baik sebagai sistem bernegara daripada pancasila terutama dalam menjamin pemerataan keadilan dari aspek hukum dan ekonomi. Pancasila dirasa oleh para guru sebagai konsepsi bernegara yang sejatinya bersifat kerakyatan, namun pada kenyatannya, banyak pihak yang dapat memonopoli hukum dan ekonomi secara sepihak. Negara tidak mampu berperan penuh melalui regulasi dan UU yang ada dimana hal itu berpangkal pada pancasila sebagai lambang negara. Selain itu, para guru (juga lebih dari 45\%) menolak islam konteks nusantara (Islam Nusantara) di Indonesia. Mereka berpendapat bahwa Islam Arab adalah islam yang murni, islam yang harus dijalankan secara mutlak. Guru percaya bahwa selain Islam yang dicontohkan oleh Rasulullah (Islam Arab) adalah bid'ah dan sesat. Berdasarkan konsep paparan radikalisme yang digagas BNPT (2018) dalam konteks ini dapat dikatakan bahwa lebih dari $45 \%$ (dari 40 guru) guru memiliki pandangan bernegara dan 
agama yang kaku (rigit). Pandangan seperti ini cenderung ideal dan keras sehingga berpotensi tinggi untuk terpapar radikalimse statis (gagasan).

Selanjutnya perlu melihat guru dalam kaitannya dengan potensi radikalisme melalui media sosial. Terlihat dari data kuesioner bahwa guru sangat tergantung (lebih dari 70\%) pada media sosial dalam berinteraksi sosial, mengakses berita, menebar emosi dan pemikiran melalui status, atau sekedar mencari konten hiburan. Meskipun dalam hal ini guru tidak sepenuhnya membernarkan konten-konten media sosial benar sepenuhnya (lebih dari 40\% TS). Namun dalam hal konteks pemberitaan berimbang, para guru lebih mempercayai kebenaran konten media sosial daripada pemberitaan TV nasional. Padahal dalam hal ini, pemerintah lebih mampu mengontrol TV nasional (kontrol sosial) daripada media sosial. Hal ini sejalan dengan tingkat responsivitas guru (lebih dari 30\%) terhadap konten-konten radikalisme yang tersebar melalui media sosial baik dalam bentuk like, commant maupun share. Dapat dikatakan tingkat kepercayaan guru terhadap media sosial yang jauh lebih tinggi daripada TV nasional menyebabkan intensitas respon guru terhadap konten-konten radikalisme cukup signifikan.

Signifikansi konten-konten radikalisme melalui media sosial tercermin dari persepsi guru mengenai konsepsi jihad atas dasar agama. Guru (lebih dari 35\%) setuju bahwa Syariat Islam wajib ditegakkan secara tegas dimana saja, dalam situasi dan kondisi apapun. Akan tetapi, guru tidak mengharamkan praktik perayaan maulid, barzanji, dzikir zaman, serta praktik keagamaan yang tidak dicontohkan nabi namun menjadi kearifan lokal yang diyakini dan dijalankan masyarakat. Dari dua hal ini dapat dicermati bahwa, guru memiliki ketegasan terhadap konsep-konsep agama yang bersifat prinsipal (aqidah atau syariat) namun membuka diri terhadap praktik keagamaan yang sesuai dengan adat istiadat serta budaya masyarakat lokal.

Sikap terbuka guru terhadap praktik keagamaan yang menyatu dengan kearifan lokal, sejalan dengan respon mereka terhadap penomena radikalisme di dunia pendidikan. Para guru (lebih dari 30\%) menyangka bahwa deklarasi HTI secara terang-terangan oleh mahasiswa di salah satu kampus di Indonesia dianggap hal yang biasa sebagai kenakalan remaja. Para guru (lebih dari 38\%) juga mengklaim bahwa tidak perlu mengklarifikasi anak-anak yang mengikuti pawai menggunakan kostum bercadar. Meski demikian, para guru (lebih dari 63\%) setuju pemberantasan konten radikalisme yang ada di buku suplemen PAUD di Bogor diusut tuntas. Dari fakta tersebut, dapat dikatakan bahwa bentuk-bentuk penomena atau kegiatan yang mengarah ke bentuk paparan radikalisme dianggap para guru sesuatu hal yang biasa, kecuali dalam hal-hal urgensi seperti konten radikalisme yang ada di buku suplemen. Hal ini karena guru tidak memahami hal-hal esensi yang dapat mengarah ke paparan radikalisme baik secara statis (gagasan) maupun aktif (tindakan) (BNPT, 2018).

\section{Pelaksanaan Pelatihan Mitigasi Radikalisme Melalui Pembelajaran Berbasis Kearifan Lokal Untuk Guru-Guru TK yang ada di Kota Palopo}

Pelaksanaan pelatihan mitigasi radikalisme berbasis kearifan lokal ini berangkat dari permasalahan bahwa makin masifnya paparan radikalisme yang mulai merebak ke lembaga-lembaga pra sekolah. Untuk membekali guru memitigasi hal tersebut, maka diadakan sebuah pelatihan mitigasi radikalisme berbasis pada nilai dan bentuk kearifan 
lokal yang selama ini berkembang dan diyakini sebagai pola tutur dan pola bertingkahlaku arif di tengah-tengah masyarakat.

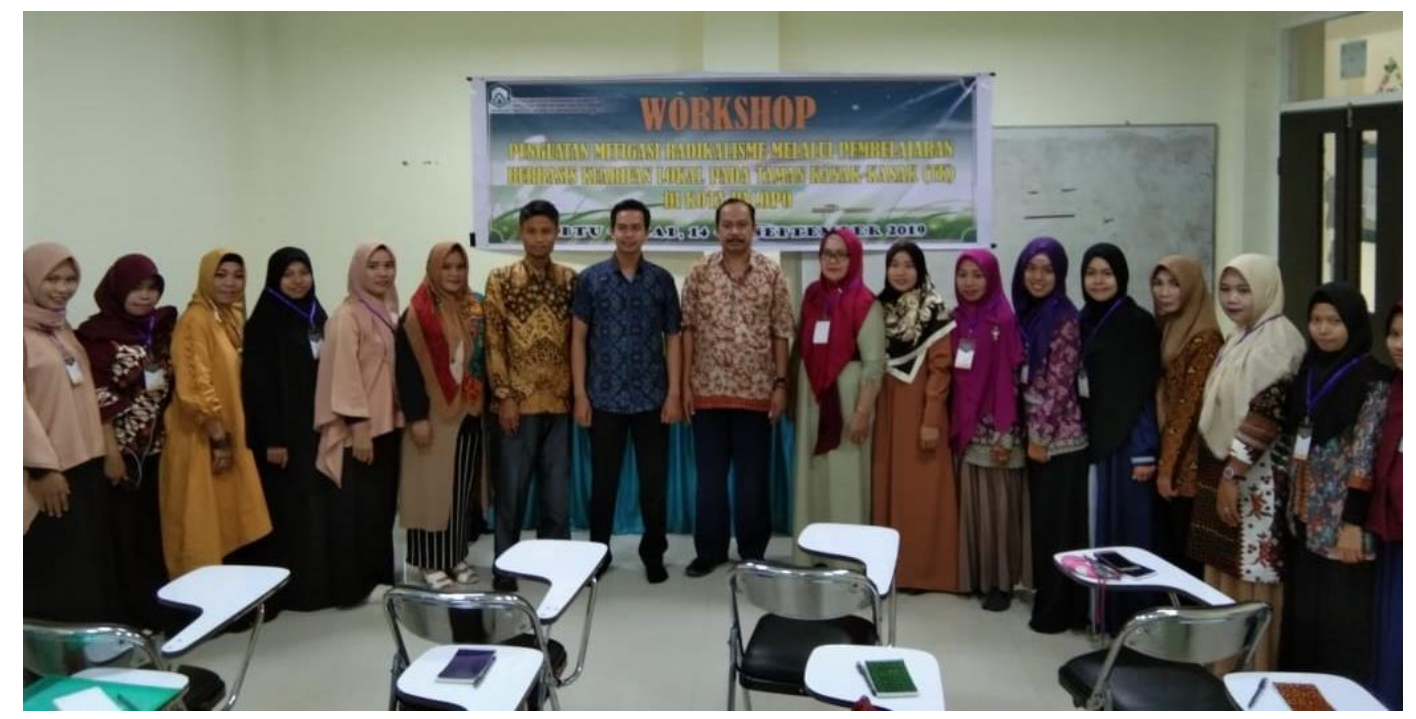

Gambar 1. Pembicara dan Peserta Pelatihan Mitigasi Radikalisme Melalui Pembelajaran Berbasis Kearifan Lokal untuk Guru TK di Kota Palopo

Dalam pelatihan ini, sasaran kemampuan konseptual dan prosedural yang ditargetkan untuk dikuasai oleh para guru berkaitan dengan mitigasi radikalisme berbasis kearifan lokal yaitu memahami konsep dasar mitigasi radikalisme dan kearifan lokal, mempolakan mitigasi radikalisme melalui kearifan lokal, memahami prinsip, unsur dan perangkat model pembelajaran mitigasi radikalisme melalui kearifan lokal, dan kemampuan merancang perangkat pembelajaran mitigasi radikalisme melalui kearifan lokal. Semuanya kompetensi tersebut dilatihkan secara terstruktur tahap demi tahap sehingga kompetensi tersebut dapat dipahami oleh peserta (guru) dengan baik.

Setelah melakukan pemetaan, tim pengabdian selanjutnya melakukan persiapan untuk menyelenggarakan pelatihan. Kepanitian tersusun atas ketua panitia, sekretaris, bendahara, pasilitator, serta para pendamping pasilitator. Setelah kepanitiaan terbentuk, panitia menyusun silabus kegiatan yang berisi nama kegiatan pelatihan yang diadakan, kompetensi capaian para peserta, alokasi waktu yang dibutuhkan, sub kompetensi dari setiap kompetensi, indikator pencapaian sub-kompetensi, materi pokok pelatihan, dan sumber belajar. Silabus tersebut kemudian disesuaikan dengan run down kegiatan harian. Run down terdiri dari batasan waktu per agenda kegiatan sekaligus fasilitator/ narasumbernya.

Selanjutnya, untuk mendukung ketercapaian kompetensi dalam silabus, disusun juga modul mitigasi berbasis kearifan lokal. Modul tersebut berisi sejumlah materi dan langkah-langkah teknis pelatihan di dalam kelas yang dibagi ke dalam 4 sesi. Sesi pertama yaitu materi tentang "konsep dasar mitigasi radikalisme dan kearifan lokal", sesi kedua yaitu "pola mitigasi radikalisme melalui kearifan lokal', sesi ketiga yaitu "prinsip, unsur dan perangkat model pembelajaran mitigasi radikalisme melalui kearifan lokal" dan sesi keempat yaitu "perancangan perangkat pembelajaran mitigasi radikalisme melalui kearifan lokal". 
Pelatihan Mitigasi Radikalisme dilaksanakan selama 2 hari, 2 sesi pada hari pertama dan 2 sesi pada hari kedua. Pelaksanaan hari pertama berkaitan dengan sesi pertama yaitu "konsep dasar mitigasi radikalisme dan kearifan lokal". Pada sesi ini, pemateri mengawali materi dengan menampilkan video melalui kanal Youtube terkait paparan radikalisme di Indonesia termasuk keterlibatan perempuan dan anak. Antusiasme para peserta pelatihan cukup tinggi, sehingga mereka banyak diberikan kesempatan oleh pemateri untuk menanggapi video tersebut berdasarkan persepsi dan pengalaman mereka. Berangkat dari pengalaman dan persepsi peserta, pemateri selanjutnya menguatkan pemahaman para peserta mengenai bagaimana pengertian mitigasi radikalisme dan kearifan lokal sekaligus hubungan keduanya. Lebih lanjut pemateri dan peserta secara bersama-sama mengidentifikasi nilai dan bentuk kearifan lokal yang berkembang di Masyarakat Luwu. Pada Akhirnya pemateri mengarahkan ke konsep selanjutnya yaitu bagaimana memitigasinya radikalisme melalui kearifan lokal setempat yakni kearifan yang berkembang di masyarakat Luwu.

Sesi berikutnya, pemateri menjelaskan "pola mitigasi radikalisme melalui kearifan lokal'. Dalam prosesnya, peserta dibagi menjadi 4 kelompok dimana setiap kelompok diarahkan untuk membuat pola hubungan (kaitan) antara unsur-unsur nilai dan bentuk kearifan lokal Luwu dengan bentuk paparan radikalisme di lembaga PAUD dalam konteks mitigasi. Semua perserta terlihat antusias berdiksusi dalam kelompoknya, mereka saling bertukar pikiran dan ide maupun pengalaman. Setelah diskusi selesai sesuai target waktu yang ditetapkan, selanjutnya pemateri mengarahkan setiap kelompok untuk mempresentasikan hasil diskusi mereka masing-masing dan kelompok lain memberikan tanggapannya. Di akhir sesi, pemateri memberikan kesimpulan dan menjelaskan pola kaitan radikalisme dengan kearifan lokal dalam konteks mitigasi yang diperkuat dengan pola dari masing-masing kelompok sebagaimana hasil presentase dan diskusi yang telah dilakukan.

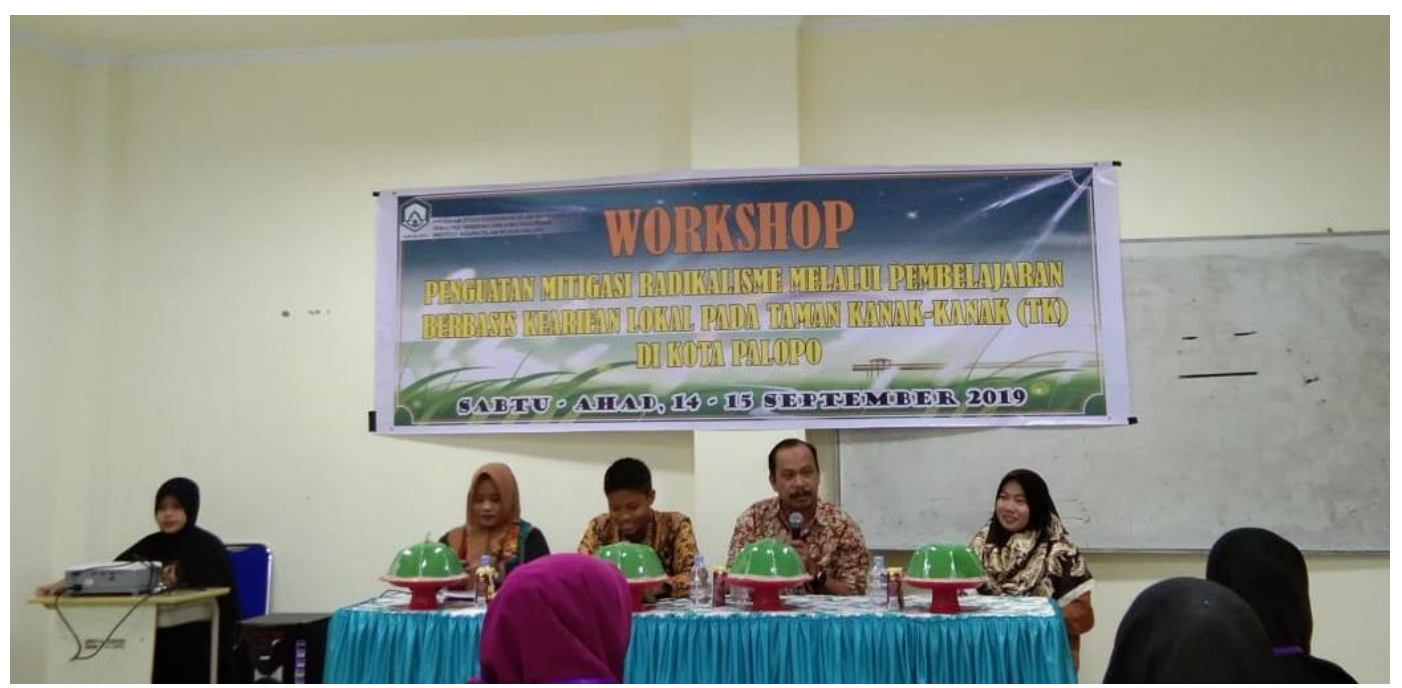

Gambar 2. Pembicara menyampaiakan materi pada pelatihan mitigasi radikalisme melalui pembelajaran berbasis kearifan lokal untuk guru TK di Kota Palopo

Pelatihan mitigasi radikalisme berbasis kearifan lokal lanjut dengan dua sesi yaitu sesi ketiga dan sesi keempat. Sesi ketiga yaitu "prinsip, unsur dan perangkat model pembelajaran mitigasi radikalisme melalui kearifan lokal” sedangkan sesi keempat yaitu 
"perancangan perangkat pembelajaran mitigasi radikalisme melalui kearifan lokal". Sesi ketiga pemateri menyampaikan bagaimana prinsip dan unsur perangkat model pembelajaran mitigasi radikalisme melalui kearifan lokal yang perlu diperhatikan oleh para peserta. Dalam sesi ini, pemateri berdiskusi dengan para peserta tentang perangkat pembelajaran berdasarkan prinsip dan unsur dari model pembelajaran mitigasi radikalisme berbasis kearifan lokal. Dalam sesi ini juga dibahas ragam pendekatan, metode, media, dan tema pembelajaran yang sesuai dengan pembelajaran mitigasi radikalisme berbasis kearifan lokal.

Setelah itu, sesi keempat yaitu "perancangan perangkat pembelajaran mitigasi radikalisme melalui kearifan lokal”. Pemateri membagi para peserta menjadi 4 kelompok dan setiap kelompok ditugaskan untuk merancang perangkat pembelajaran yang dimulai dengan membuat jaring tema, membuat kegiatan harian (RPPH), merancang media pembelajaran yang sesuai, serta melakukan simulasi pembelajaran mitigasi radikalisme berbasis kearifan lokal.

Setelah semua proses selesai, panitia mengadakan penilaian terhadap penguasaan kompetensi konseptual mitigasi radikalisme melalui pembelajaran berbasis kearifan lokal, kompetensi konseptual mitigasi radikalisme melalui pembelajaran berbasis kearifan lokal dan aktivitas peserta selama pelatihan berlangsung. Rata-rata jumlah peserta pelatihan yang dianggap kompten dan aktif dalam pelatihan adalah $88 \%$ dari 40 jumlah peserta yang mengikuti pelatihan. Menurut para peserta, masih sulit dalam menyesuaikan tema dengan nilai dan bentuk kearifan lokal yang akan diimplementasikan dalam pembelajaran. Ketika simulasi, masih banyak peserta yang belum maksimal karena tidak terbiasa melakukan microteaching sebelumnya. Peserta dalam hal ini ratarata masih kesulitan dalam melakukan simulasi pembelajaran karena masih kesulitan memilih aspek radikalisme dengan teknis pelaksanaan pembelajaran yang diterapkan. Terutama dalam merangkai perangkat dan menggunakan media mitigasi secara tepat dan akurat. Kendala-kendala ini diselesaikan dengan melakukan pendampingan individual dan diskusi secara klasikal.

\section{Efektivitas Mitigasi Radikalisme Melalui Pembelajaran Berbasis Kearifan Lokal pada Lembaga Taman Kanak-Kanak (TK) di Kota Palopo}

Epektivitas penerapan pengabdian dilihat dari tingkat penguasaan kompetensi konsep dan teknis mitigasi radikalisme melalui pembelajaran berbasis kearifan lokal. Uji epektivitas dilakukan selama proses pelaksanaan pelatihan. Indikator epektiftivitas dalam yang ditetapkan tim pengabdian yaitu apabila terjadi perubahan persepsi guru yang ditandai dengan perubahan skor berbagai butir kuesioner radikalisme yang diberikan pada tahapan pemetaan.

Untuk melihat perubahan tersebut, data yang diperoleh dari kuesioner sebelum pelaksanaan pelatihan (tahapan pemetaan) dijadikan sebagai data pre test. Sementara itu, data post test diperoleh dari isian kuesioner yang sama setelah selesai seluruh rangkaian pengabdian dilakukan termasuk tahapan monitoring \& evaluasi dan tindak lanjut.

Dalam pengukuran yang dilakukan terhadap kompetensi konseptual mitigasi radikalisme melalui pembelajaran berbasis kearifan lokal, secara keseluruhan peserta pelatihan telah mampu mencapai kompetensi yang diharapkan. Rata-rata jumlah peserta 
yang telah menguasai kompetensi konseptual mitigasi radikalisme melalui pembelajaran berbasis kearifan lokal yaitu $90 \%$ atau 36 orang dari setiap aspek kompetensi yang ada dalam silabus pelatihan. Dengan demikian, hal ini dapat dikatakan bahwa pelaksanaan pelatihan epektif dalam meningkatkan kompetensi konseptual para peserta (guru).

Dalam rangka melihat penguasaan kompetensi teknis peserta, dilakukan penilaian terhadap perangkat pembelajaran yang dibuat selama pelatihan. Data hasil tes menunjukkan bahwa sebanyak 34 peserta (85\%) dapat membuat perangkat pembelajaran mitigasi radikalisme berbasis kearifan lokal sesuai dengan kriteria yang ditetapkan. Angka ini merepresentasikan bahwa mayoritas peserta telah mampu membuat perangkat dengan baik melalui pelatihan yang telaah diikuti. Paling banyak peserta (7 orang) belum mampu dalam hal membuat jaring tema dan mensimulasikan pembelajaran. Menurut para peserta, masih sulit dalam menyesuaikan tema dengan nilai dan bentuk kearifan lokal yang akan diimplementasikan dalam pembelajaran. Ketika simulasi, masih banyak peserta yang belum maksimal karena tidak terbiasa melakukan microteaching sebelumnya.

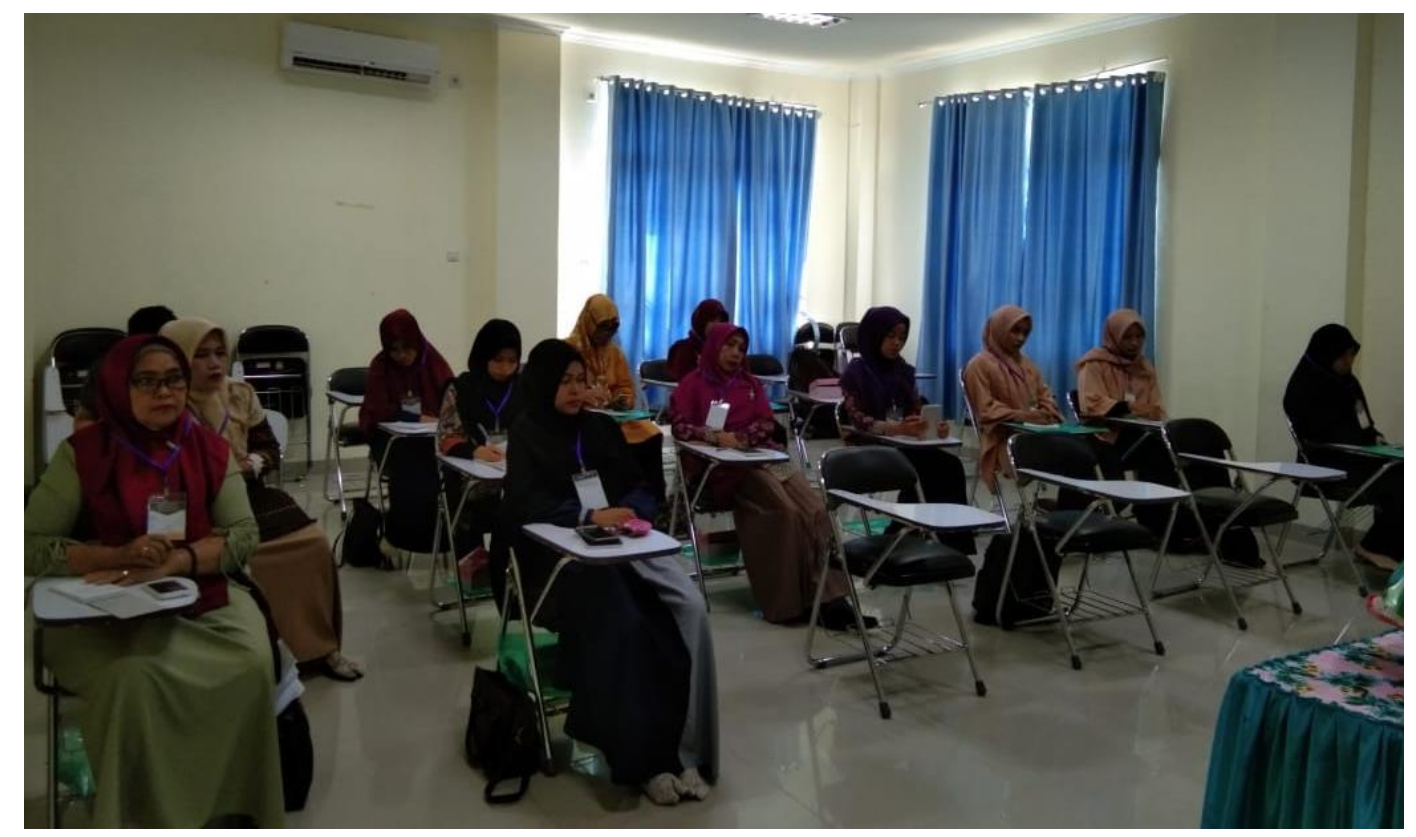

Gambar 3. Peserta Pelatihan Mitigasi Radikalisme Melalui Pembelajaran Berbasis Kearifan Lokal untuk Guru TK di Kota Palopo

Disamping itu, simulasi pembelajaran juga masih terdapat 7 orang yang dinyatakan belum mampu melakukannya dengan baik. Kendala yang dialami, yaitu masih kesulitan memilih aspek radikalisme dengan teknis pelaksanaan pembelajaran yang diterapkan. Terutama dalam merangkai perangkat dan menggunakan media mitigasi secara tepat dan akurat.

Di samping mengukur kompetnsi konseptual dan teknis peserta, pada pelatihan ini perlu juga melihat keaktifan peserta dalam proses pelaksanaan pelatihan. Hasil observasi yang dilakukan oleh tim pengabdian. Dari skoring yang ada, dapat dilihat bahwa sebagian besar peserta telah terlibat aktif dalam rangkaian pelaksanaan pelatihan mulai dari intensitas kehadiran, diskusi dalam kelompok sampai pada kegiatan simulasi 
pembelajaran. Rata-rata sebanyak 36 atau 90\% peserta aktif terlibat pada proses pelaksanaan pelatihan. Hanya 5 peserta atau sekitar $10 \%$ peserta dinyatakan belum terlibat secara maksimal. Hal ini terutama kurangnya inisiatif peserta untuk mencatat hal penting, bertanya apabila menemukan kendala atau ada bagian materi yang tidak dipahaminya dan masih kurang maksimal dalam proses simulasi pembelajaran.

Berdasarkan hal tersebut di atas, dapat dikatakan bahwa pelatihan tersebut efektif meningkatkan kemampuan mitigasi radikalisme melalui pembelajaran berbasis kearifan lokal. Efektif dalam hal meningkatkan kompetensi konseptual, teknis, dan keaktifan (motivasi) peserta ketika mengikuti pelatihan.

\section{Kesimpulan}

Pelatihan mitigasi radikalisme berbasis Paparan radikalisme yang di lembaga TK di Kota Palopo sudah berada pada tahapan "responsif" artinya telah ada potensi terpapar radikalisme secara statis (radikalisme gagasan/pemikiran/ide) namun sudah berada ke fase transisi tindakan (radikalisme aktif) dalam konteks terntentu yang masih dapat ditoleransi "wajar". Selama proses pelatihan berlangsung para peserta dibekali dengan kemampuan konseptual dan teknis selama 2 hari yang terbagi dalam 4 sesi yang didalamnya terjabar konsep dasar, pola, model, rancangan serta simulasi pembelajaran mitigasi radikalisme berbasis kearifan lokal. Keseluruhan sesi berjalan sesuai dengan perencanaan terbukti dari tingginya prosentase jumlah peserta (guru) yang mampu menguasai kompetensi capaian dan aktif terlibat dalam keseluruhan proses pelatihan.

\section{Ucapan Terimakasih}

\section{Referensi}

Arsanti, M. (2014). Pemerolehan Bahasa Pada Anak (Kajian Psikolinguistik). 3(2), 24.

Esposito, J. L. (1997). Political Islam: Revolution, Radicalism of Reform? Lynne Raenner Publishers.

Fahmi, D., \& Ichsan, A.-T. (2018). Upaya Meningkatkan Kecerdasan Interpersonal Anak Melalui Bermain Peran Di TK Aba Karanganyar Yogyakarta Tahun Ajaran 20172018. Golden Age Jurnal Tumbuh Kembang Anak Usia Dini, 3(1), 1-18.

Feldman, R. S. (2014). Child Development: A Topical Approach. Pearson.

Fuad, A. J. (2018). Gerakan Kultural dan Pemberdayaan: Sebuah Imun atas Radikalisasi di Sanggar Sekar Jagad di Sukoharjo. Al-Tahrir: Jurnal Pemikiran Islam, 18(1), 1-22. https://doi.org/10.21154/altahrir.v18i1.1171

Golberstein, E., Wen, H., \& Miller, B. F. (2020). Coronavirus Disease 2019 (COVID-19) and Mental Health for Children and Adolescents. JAMA Pediatrics, 174(9), 819-820. https://doi.org/10.1001/jamapediatrics.2020.1456

Hafni, N. D. (2019). Nomophobhia, Penyakit Masyarakat Modern. Al-Hikmah: Jurnal Kependidikan Dan Syariah, 6(2), 41-50.

Khasanah, I. (2013). Program "SAHABAT" Sebagai Salah Satu Program Alternatif Penanganan Bullying Pada Anak Usia Dini. Jurnal Pendidikan Anak, 2(2), Article 2. https://doi.org/10.21831/jpa.v2i2.3049 
Kompas Media, C. (2013, June 7). Empat Orang Tes DNA untuk Pelaku Bom Poso. KOMPAS.com.

https://regional.kompas.com/read/2013/06/07/20021921/ Nasional

Kongprasertamorn, K. (2007). Local Wisdom, Environmental Protection and Community Development: The Clam Farmers in Tambon Bangkhunsai, Phetchaburi Province, Thailand. Manusya: Journal of Humanities, 10(1), 1-10. https://doi.org/10.1163/26659077-01001001

Kusuma, R. S., \& Azizah, N. (2018). Melawan Radikalisme melalui Website. Jurnal ASPIKOM, 3(5), 943-957. https://doi.org/10.24329/aspikom.v3i5.267

Meliono, I. (2011). Understanding the Nusantara Thought and Local Wisdom as an Aspect of the Indonesian Education. TAWARIKH, 2(2), Article 2. https://doi.org/10.2121/tawarikh.v2i2.392

NakhornThap, S. (1996). Participation, Report of the Study on Patterns of Process in Promoting Teacher and School On, for Prevention and Solution of Problems Concerning Child Labor in Thailand. Journal of Research on Humanities Information Study.

Neaum, S. (2010). Child Development for Early Childhood Studies. SAGE.

Percy, A. K. (2006). Handbook of Neurodevelopmental and Genetic Disorders in Adults. Neurology, 67(9), 1728-1728-a. https://doi.org/10.1212/01.wnl.0000217540.04266.8e

Permana, C. E., Nasution, I. P., \& Gunawijaya, J. (2012). Kearifan Lokal Tentang Mitigasi Bencana Pada Masyarakat Baduy. Hubs-Asia, 10(1), Article 1. http://hubsasia.ui.ac.id/old/index.php/hubsasia/article/view/954

Pornpimon, C., Wallapha, A., \& Prayuth, C. (2014). Strategy Challenges the Local Wisdom Applications Sustainability in Schools. Procedia - Social and Behavioral Sciences, 112, 626-634. https://doi.org/10.1016/j.sbspro.2014.01.1210

Pratiwi, H. (2018). Redefinisi Peran Orang Tua Dalam Pendidikan; Penanaman Sikap Anti Radikalisme Sejak Usia Dini. Madrasah: Jurnal Pendidikan Dan Pembelajaran Dasar, 10(2), 96-110. https://doi.org/10.1886o/madrasah.v10i2.5111

Rokhmad, A. (2012). Radikalisme Islam Dan Upaya Deradikalisasi Paham Radikal. Walisongo: Jurnal Penelitian Sosial Keagamaan, 20(1), 79-114. https://doi.org/10.21580/ws.20.1.185

Schofield, P. (2004). Jeremy Bentham, the French Revolution and political radicalism. History of European Ideas, 30(4), 381-401. https://doi.org/10.1016/j.histeuroideas.2003.11.019

Sesmiarni, Z. (2015). Membendung Radikalisme Dalam Dunia Pendidikan Melalui Pendekatan Brain Based Learning. KALAM, 9(2), 233-252. https://doi.org/10.24042/klm.vgi2.330

Wahidy, A. (2018). Budaya Dan Kearifan Lokal Sebagai Benteng Radikalisme. Prosiding Seminar Nasional Program Pascasarjana Universitas PGRI Palembang, o(o), Article o. https://jurnal.univpgripalembang.ac.id/index.php/Prosidingpps/article/view/1513

Widyaningsih, R., Sumiyem, S., \& Kuntarto, K. (2017). Kerentanan Radikalisme Agama Di Kalangan Anak Muda. Prosiding, 7(1), Article 1. http://jurnal.Ippm.unsoed.ac.id/ojs/index.php/Prosiding/article/view/553 
Wong, M. Y. H., Khiatani, P. V., \& Chui, W. H. (2019). Understanding youth activism and radicalism: Chinese values and socialization. The Social Science Journal, 56(2), 255-267. https://doi.org/10.1016/j.soscij.2018.08.006

Yusof, K., \& Nasir, B. M. (2010). Islamic Radicalism in Malaysia: Gender perspective. 5(Procedia Social and Behavioral Sciences 5), 2119-2125. https://doi.org/10.1016/j.sbspro.2010.07.424

Zidni, E. S. Z. (2018). Kemitraan Keluarga dalam Menangkal Radikalisme. Jurnal Studi AlQur'an, 14(1), 32-43. https://doi.org/10.21009//SQ.014.1.03 